\title{
THE DISPERSION OF THE APHANOMYCES ASTACI-CARRIER PACIFASTACUS LENIUSCULUS BY HUMANS REPRESENTS THE MAIN CAUSE OF DISAPPEARANCE OF THE INDIGENOUS CRAYFISH AUSTROPOTAMOBIUS PALLIPES IN NAVARRA
}

\author{
J. DIÉGUEZ-URIBEONDO
}

Departamento de Micología, Real Jardín Botánico CSIC, Plaza Murillo 2, 28014, Madrid, Spain.

E-Mail: dieguez@ma-rib.csic.es

Reçu le 21 juin 2005

Accepté le 22 décembre 2005

Received June 21, 2005

Accepted December 22, 2005

\begin{abstract}
The tendency of population decline of the indigenous crayfish, Austropotamobius pallipes, in Navarra was reduced by the implementation of a plan of restoration in 1996. Recently, a new drop in population numbers has been noticed. In 2004, an extensive survey was carried out to study the reasons for this decline. The results showed that indigenous crayfish had disappeared from 37 out of 73 areas where they were previously present. The main causes were found to be: presence of signal crayfish, Pacifastacus leniusculus (40\%), habitat alterations (13\%) and climatic drought $(11 \%)$. In $35 \%$ of the cases, the reasons could no be determined. Disappearances that were associated with presence of signal crayfish were assigned to crayfish plague. These disappearances have occurred a few years after an increase in the number signal crayfish fishery areas. The new populations of $P$. leniusculus followed a patchy distribution, and were clearly associated with human introductions. This work shows that signal crayfish currently represents the main reason for decline of indigenous crayfish and that humans play a major role in the dispersal of these carriers of the causative organism of crayfish plague, $A$. astaci.
\end{abstract}

Key-words: Aphanomyces, Austropotamobius, Pacifastacus, epidemiology, conservation, management.

\section{LA DISPERSION DE PACIFASTACUS LENIUSCULUS PAR L'HOMME REPRÉSENTE LA PRINCIPALE CAUSE DE LA DISPARITION DES POPULATIONS DE L'ÉCREVISSE INDIGÈNE AUSTROPOTAMOBIUS PALLIPES EN NAVARRE}

\section{RÉSUMÉ}

La tendance au déclin des populations de l'écrevisse indigène, Austropotamobius pallipes, en Navarre a diminue suite à la mise en œuvre d'un plan de restauration depuis 1996. Récemment, une nouvelle chute du nombre de populations a été notée. En 2004, un large suivi a été entrepris en Navarre pour étudier les raisons de ce déclin. Les résultats ont montré que l'écrevisse indigène a disparu de 37 des 73 sites où elles étaient présentes. Les principales causes sont la présence de l'écrevisse de Californie, Pacifastacus leniusculus (40\%), l'altération de l'habitat (13\%) et les assecs (11\%). Dans $35 \%$ des cas, les raisons n'ont pu être déterminées. Les disparitions associées à la présence de l'écrevisse de Californie sont assignées à la peste de l'écrevisse. Les nouvelles populations de l'écrevisse de Californie sont dispersées, et sont clairement 
attribuées à l'introduction par l'homme. Les disparitions sont apparues quelques années après une augmentation du nombre de sites de pêche pour l'écrevisse de Californie. Ce travail montre que l'écrevisse de Californie représente la principale raison du déclin de l'écrevisse indigène et que l'homme joue un rôle majeur dans la dispersion de ces porteurs de l'organisme responsable de la peste de l'écrevisse, Aphanomyces astaci.

Mots-clés: Aphanomyces, Austropotamobius, Pacifastacus, épidémiologie, conservation, gestion.

\section{INTRODUCTION}

Indigenous crayfish, Austropotamobius pallipes (Lereboullet, 1858) populations of the Iberian Peninsula experienced a dramatic decline in the 1970s as consequence of the crayfish plague (CUELLAR and COLL, 1983; DIÉGUEZ-URIBEONDO et al., 1997a, b), a disease caused by the heterokont organism, Aphanomyces astaci (Schikora 1903). European and Australasian species of crayfish die rapidly after infection by $A$. astaci (UNESTAM, 1969). However, North American species exhibit a higher resistance to this particular parasite (UNESTAM, 1972; CERENIUS et al., 2003). The pathogen, A. astaci, is endemic of North America and, at least, three species of crayfish of this continent are known to carry $A$. astaci in their cuticle, i.e. the signal crayfish Pacifastacus leniusculus (Dana, 1852), the spiny-cheek crayfish Orconectes limosus (Rafinesque 1817) and the swamp crayfish Procambarus clarkii (Girard, 1852), (PERSSON and SÖDERHÄLL, 1983; VEY et al., 1983; DIÉGUEZ-URIBEONDO et al., 1995). So far, three groups of $A$. astaci have been spread in Europe and named A, B and D. Group A is believed to represent isolates that originated from an early introduction of this parasite into Europe, group B consists of strains isolated from $P$. leniusculus or from outbreaks of indigenous European crayfish after introduction of this crayfish into Sweden in 1969 (HUANG et al., 1994); and group D includes strains isolated from P. clarkii in Spain (DIÉGUEZ-URIBEONDO et al., 1995).

Specimens of P. clarkii and P. leniusculus were introduced into Spain in 1973 and 1974 (DIÉGUEZ-URIBEONDO et al., 1997b; ALONSO et al., 2000). The wide range distribution and abundance of the indigenous crayfish facilitated the rapid spread of the plague. Thus, the West-Pyrenean region of Navarra was reached by the disease in 1979 (CUELLAR and COLL, 1983). Few years later, most $A$. pallipes populations disappeared, and crayfish catching was banned. The surviving populations were basically thriving in headwaters and ponds away from the risk of transmission of the disease. In the region of Navarra, surveys carried out in 1986 and 1991 recorded only 63 and 55 populations of indigenous crayfish, respectively (DIÉGUEZ-URIBEONDO et al., 1997a). As a result, the local Government of Navarra listed this species as being at risk of extinction, and implemented a plan of restoration for indigenous crayfish and a plan of management for exotic species in 1996 (DIÉGUEZ-URIBEONDO et al., 1997a). The purposes of these plans were to preserve and re-establish populations of $A$. pallipes by eradicating or minimizing the factors responsible for the regression of its populations, and to prevent the spread of exotic crayfish. The implemented plan established two areas (see Figure 1A): a) an "indigenous crayfish area" that comprises all watercourses where the species A. pallipes occurs, and also a no-go area that extends to an, b) "exotic species area", in which the majority of exotic crayfish populations are found and attempts to restore indigenous populations are extremely complicated. In this area, catching exotic crayfish is allowed while in the "indigenous crayfish area" the capture of exotic crayfish is only allowed if a special policy is implemented (DIÉGUEZ-URIBEONDO et al., 1997a). The implementation of this plan turned out to have a positive impact on indigenous crayfish populations. The tendency of decline of $A$. pallipes was reversed as judged by results of surveys carried out in 1997, 1999 and 2001 (DIÉGUEZ-URIBEONDO and MÚZQUIZ, 1999; ALONSO et al., 2000; DIÉGUEZ-URIBEONDO, unpublished). However, during the period of 1999 until 
present the regulations banning signal crayfish catching in the "indigenous crayfish area" have been modified according to the demands of local fishermen and more rivers have become accessible for catching exotic species with a limited policy (Orden Foral 146, 1999). This has raised the concern of a negative impact of the implementation of these regulations on indigenous crayfish. Thus, the purpose of this study was to investigate the current status of $A$. pallipes populations, and the consequences of the new regulations implemented in Navarra.

\section{MATERIAL AND METHODS}

\section{Survey and site selection}

The survey was undertaken between July 1st and September 30th of 2004 in catchments, ponds and artificial lakes located in the "indigenous crayfish area" of Navarra that showed positive presence of $A$. pallipes in a previous survey carried out in 2001 . The exact location of the sites is omitted because of conservation purposes.

Presence of crayfish was determined by manual searching and trapping. The manual searching was carried out moving from upstream to downstream on each of the brooks sampled. Trapping was performed by using an average of ten baited traps that were left overnight at five different locations of the site studied, placed in lakes, ponds and deep pools that are not suitable for hand searching. A total of 73 sites were examined. A site was assessed as positive for harboring indigenous crayfish if they were captured, seen or if moults of indigenous crayfish were detected. However, if indigenous crayfish were not captured nor observed the site was assessed as negative.

\section{Assessment of reasons for indigenous crayfish disappearance}

Whenever, the sampling of indigenous crayfish was negative, the reasons for their absence were investigated. The following aspects were taken into account: presence of dead indigenous crayfish, presence of North American crayfish species in the same stream or catchment, severe stream-flow drought, d) habitat alterations due to human activities such as channelization, route constructions, water pollution, etc. If any exotic crayfish were seen, these were captured and sent for health control analysis. If dead indigenous crayfish were observed, specimens were collected in refrigerated cool humid boxes and sent for diagnosis.

\section{Health controls}

In streams and ponds where North American crayfish were observed, a sample of 10 specimens was taken, if possible. Crayfish were examined for the presence of A. astaci. The crayfish were examined for the occurrence of "black spots", i.e. melanized areas in their cuticle (SÖDERHÄLL et al., 1991; DIÉGUEZ-URIBEONDO et al., 1997b), and isolations of the causative agent were attempted. For this purpose, pieces of cuticle with melanized spots from legs of live specimens were cut out and washed carefully first with ethanol and, then, several times with sterile distilled water, and examined under an inverted microscope. When hyphal growth was observed a piece of the infected area was placed on peptone glucose medium to allow mycelial growth (PG-1) (SÖDERHÄLL and CERENIUS, 1987). When specimens of dead indigenous crayfish were examined for the presence of crayfish plague, the $A$. astaci isolation was done according to CERENIUS et al. (1988). In order to determine the genus, the isolates were induced to sporulate in drops cultures as described by DIÉGUEZ-URIBEONDO et al. (1994). When typical sporangia of Aphanomyces were observed, single spore isolates were obtained and maintained as pure cultures for RAPD-PCR characterization. 


\section{DNA Preparation and RAPD-PCR}

The strains included for comparisons were L1 (group A from Astacus astacus), strain Tl (group B from P. leniusculus), and strain Pc (group D from P. clarkii). These strains were kindly provided by Dr. Cerenius from Uppsala University. The isolated strains were cultivated in PG-1 drop cultures as described in SÖDERHÄLL and CERENIUS (1987). DNA was extracted using E.Z.N.A. Fungi DNA miniprep kit (Omega Biotek, Doraville, USA). About $10 \mathrm{mg}$ of fresh mycelium from PG-1 drop cultures were used for the DNA isolation. The PCR-reactions were carried out as described in HUANG et al., (1994) except that the primer concentration was 200 nM. Diagnostic primer B01 was used for analysis.

\section{RESULTS}

Of the 73 sites investigated for the presence of $A$. pallipes (Figure 1B) only 36 were confirmed to have this species (Figure 1C). In the majority of the cases, the indigenous crayfish populations were not dense and their distribution within the survey area was small and fragmented. During the period of survey, information regarding the presence of new populations of $A$. pallipes was obtained from local people. These sites were sampled as described in material and methods. A total of 17 new positive sites for the indigenous crayfish were found (Figure 1D).

Among the possible reasons for disappearance, it was found that in 15 out of 37 cases, signal crayfish specimens were found in the same stream from where indigenous species had vanished. This represented about $40 \%$ of the cases (Figure 2). No coexistence of indigenous and exotic crayfish was ever observed. In 3 out of those 15 cases described above, indigenous crayfish outbreaks were observed in situ and diagnosed as crayfish plague. In 5 cases out of the 37 disappearances, habitat alterations of different nature such as road construction affecting the stream, channelization, and organic pollution from farm wastes were responsible for indigenous crayfish disappearances. The habitat alterations accounted for about $13 \%$ of disappearances. Climatic drought was the cause of loss in 4 cases (11\%). In these sites, no water was flowing in the streams and no crayfish were found in downstream sites. In 13 sites, the causes for disappearance could not be determined, which represented $35 \%$ of the cases (Figure 2). However, it was noticed that in the majority of the cases signal crayfish populations were thriving in the same basin as vanished populations of indigenous crayfish.

All the signal crayfish populations studied were found to have signs of crayfish plague, i.e. black spots, in population rates that ranged from 0.1 to 0.4 spots per crayfish. From all studied populations, isolates of Aphanomyces sp. were obtained. RAPD analysis of Aphanomyces sp. strains isolated from signal crayfish, named Cs, and from specimens of $A$. pallipes, named $\mathrm{Na}$, showed that all isolates exhibited the same band pattern as representative strain of $P$. leniusculus group (Figure 3 ). Therefore, the isolates were assigned to group $B$, which includes isolates from signal crayfish, and from indigenous European crayfish struck by the plague after large scale stocking of signal crayfish in Europe.

In sites where signal crayfish has substituted the indigenous species, disappearances of $A$. pallipes were assigned to crayfish plague since: (i) the signal crayfish found were carrying $A$. astaci, (ii) no coexistence of indigenous and exotic crayfish was observed, (iii) in three cases, mortalities among indigenous crayfish were diagnosed as due to crayfish plague, and (iv) isolated strains of $A$. astaci belonged to group $\mathrm{B}$, characteristic of the known plague carrier $P$. leniusculus.

The new populations of $P$. leniusculus in the stream previously inhabited by indigenous crayfish followed a patchy distribution and were geographically distant and in different stream catchments than previously reported signal crayfish populations. 

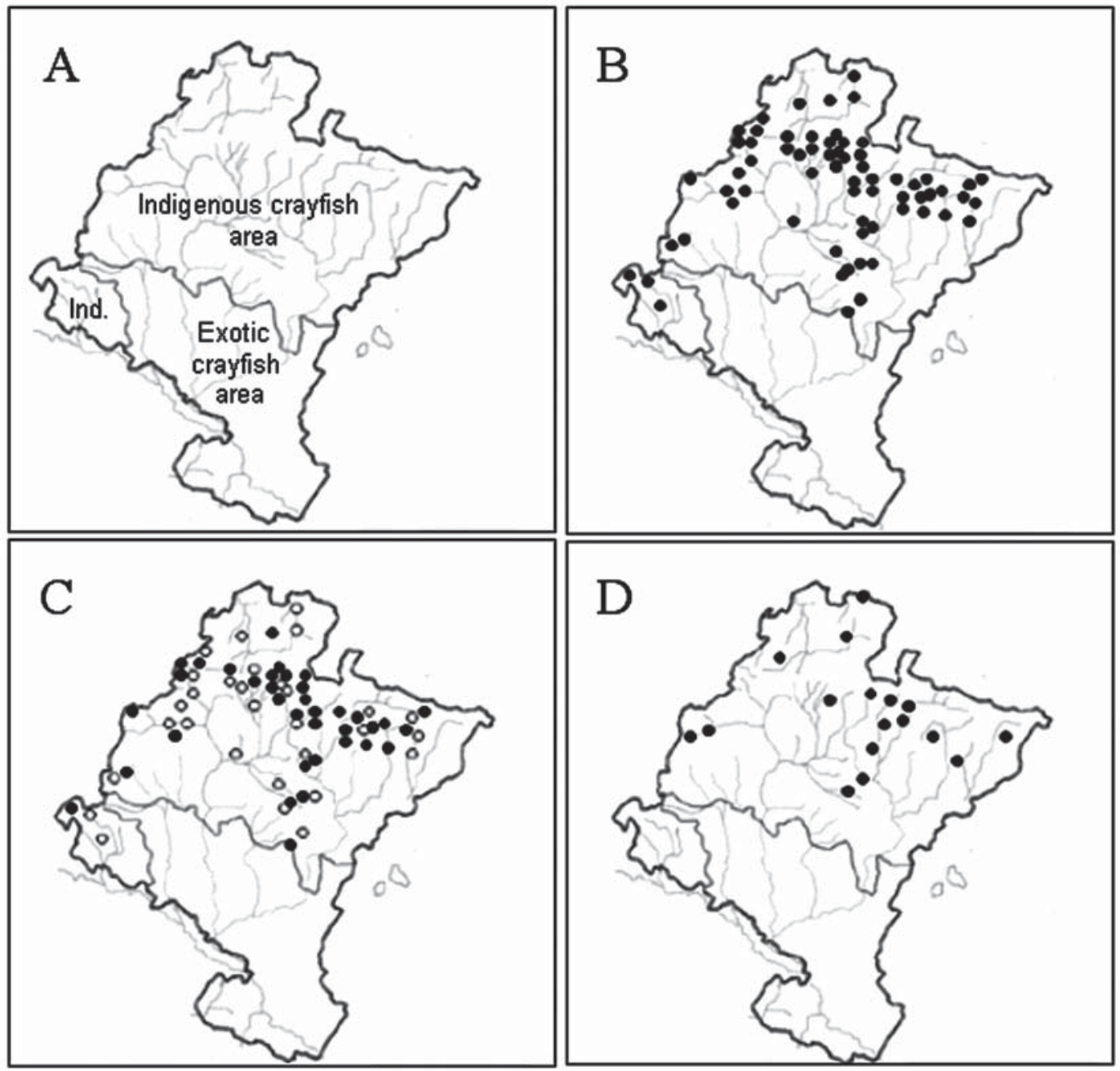

Figure 1

A, Plan of restoration of the indigenous crayfish Austropotamobius pallipes in Navarra. For practical reasons, the plan defines two theoretical areas: the indigenous crayfish area and the exotic crayfish area. The indigenous crayfish area comprises streams, ponds and lakes with indigenous crayfish populations and a non-go area that extends to the exotic crayfish area. The latter, basically comprises middle river stretches that are inhabited by exotic crayfish, i.e. red swamp crayfish, Procambarus clarkii and the signal crayfish Pacifastacus leniusculus. B, Survey of 2001: ( $\bullet$ ) positive sites for indigenous crayfish in Navarra. C, Survey of 2004: ( $)$ positive sites for indigenous crayfish, $(0)$ sites from where indigenous crayfish has disappeared since last survey in 2001. D, Survey of 2004: (•) new positive sites for indigenous crayfish.

Figure 1

A, Plan de restauration de l'écrevisse indigène Austropotamobius pallipes en Navarre. Pour des raisons pratiques le plan comprend deux aires théoriques: celle pour l'écrevisse indigène et celle pour les écrevisses exotiques. L'aire de distribution de l'écrevisse indigène comprend les cours d'eau, les mares et les lacs où sont présentent les population d'écrevisses indigènes et une aire interdite où se trouvent les écrevisses exotiques. Cette dernière comprend les rivières moyennes où habitent les écrevisses exotiques, l'écrevisse de Louisiane, Procambarus clarkii et l'écrevisse de Californie, Pacifastacus leniusculus.B, Distribution en 2001: (•) sites où est présente l'écrevisse indigène en Navarre. C, Distribution en 2004: $(\bullet)$ sites où est présente l'écrevisse indigène en Navarre.

(o) Sites où l'écrevisse indigène a disparu depuis le dernier recensement en 2001.

$D$, distribution en $2004,(\bullet)$ nouveaux sites à écrevisse indigène. 


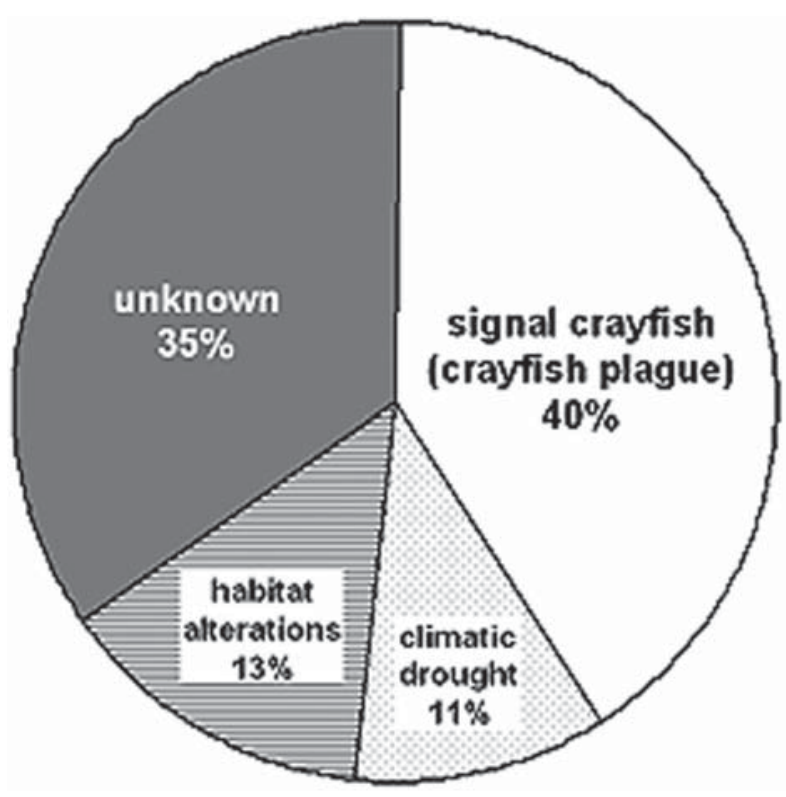

Figure 2

Relative incidence of the factors involved in disappearance of the native crayfish Austropotamobius pallipes in the region of Navarra. A total of 37 cases of native crayfish disappearances were investigated. In 15 out of 37 cases of disappearances, signal crayfish specimens were found in the same stream, in which native species had vanished. In 5 cases, the reasons of disappearance were due to habitat alterations. Climatic drought was the cause of loss in 4 cases. At 13 occasions the causes could not be determined.

Figure 2

Incidence relative des facteurs impliqués dans la disparition de l'écrevisse native Austropotamobius pallipes dans la région de Navarre. Un total de 37 cas de disparition a été étudié. Dans 15 des 37 cas de disparition, l'écrevisse de Californie a été trouvée dans le même cours d'eau où l'espèce native était présente. Dans 5 cas, les raisons sont dues à l'altération de l'habitat. La sècheresse a entraîné la disparition de 4 populations. Dans 13 cas, les causes n'ont pu être déterminées.

\section{DISCUSSION}

The main reason for indigenous crayfish decline in Navarra was crayfish plague followed by habitat alterations and climatic drought. Crayfish plague was responsible of, at least, $40 \%$ of cases of the indigenous crayfish disappearances. This figure showns a higher incidence of crayfish plague in Navarra than in a previous study carried out in the province of Burgos (ALONSO et al., 2000). These differences are, however, more likely due to the criteria followed to assign disappearances of indigenous species to crayfish plague. In this study, it was taken into account the proximity of $A$. astaci species carriers and the presence of $A$. astaci was always confirmed when disappearances were assigned to crayfish plague.

Signal crayfish represents the main factor favoring the dispersal of crayfish plague in Navarra. There are numerous studies showing the role of signal crayfish as a carrier of crayfish plague (see review CERENIUS and SODERHALL, 1999) and the relationship of this exotic crayfish to a large number of epizootics has been consistently proven (HUANG et al., 1994; LILLEY et al., 1997; VENNERSTRÖM et al., 1998; OIDTMANN 


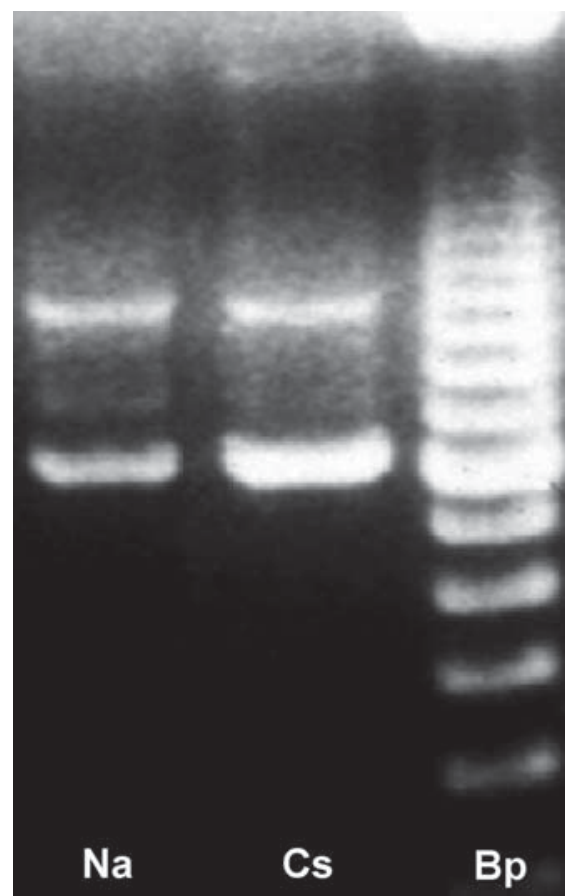

\section{Figure 3}

Typical RAPD-PCR profile of Aphanomyces astaci strains belonging to group B (this group consists of isolates from signal crayfish, Pacifastacus leniusculus and from indigenous crayfish outbreaks on of signal crayfish origin). Note similarity between the representative isolate from outbreaks on indigenous crayfish in Navarra and the representative isolate from naturalized signal crayfish in Navarra. The RAPD-PCR profiles were obtained with primer B01. From, left: $A$. astaci isolates Na, Cs (Group B), and 100bp-ladder (BL) (Pharmacia).

\section{Figure 3}

Profil typique de PCR-RAPD de souches d'Aphanomyces astaci appartenant au groupe $\mathrm{B}(\mathrm{Ce}$ groupe a été isolé à partir de l'écrevisse de Californie, Pacifastacus leniusculus et à partir d'écrevisses indigènes mortes et infectées par $\boldsymbol{P}$. leniusculus). Notez la similitude des isolats entre ceux présents chez l'écrevisse indigène et chez l'écrevisse de Californie. Les profils de PCR-RFLP ont été obtenus avec les amorces BO1.

et al., 1999; DIÉGUEZ-URIBEONDO and SÖDERHÄLL, 1999). The results of this study are in agreement to BOHMAN et al. (2006). These authors have recently found a positive correlation between the number of crayfish plague outbreaks and the increase in number of signal crayfish populations in Sweden. In Navarra, signal crayfish could be responsible of more cases of disappearances of indigenous crayfish because this species is present in the majority of river sub-basins of Navarra where indigenous is thriving. In Spain, the presence of signal crayfish in the same sub-basin as indigenous crayfish has been shown, at two occasions, to be the origin of transmission of crayfish plague to $A$. pallipes (DIÉGUEZ-URIBEONDO and SÖDERHÄLL, 1999). The red swamp crayfish, P. clarkii, appears to have been the main way of dispersal of A. astaci in 1970's and 1980's in Spain (DIÉGUEZ-URIBEONDO et al., 1997a; ALONSO et al., 2000). However, this crayfish species does not seem to be involved in the current indigenous crayfish decline observed in this study. This is not surprising since this species is not thriving in the same catchments 
inhabited by indigenous crayfish in Navarra, and also because fishermen currently prefer introducing signal crayfish to the red swamp crayfish.

In this work, it is shown that $P$. leniusculus (and, consequently, of $A$. astaci) is being efficiently spread by humans rather than by natural means. The new signal crayfish populations are geographically distant and are not continuous with previously known populations of signal crayfish in Navarra. Natural spread of signal crayfish is known to occur at a low rate (BOHMAN et al., 2006) and cannot explain the distribution of new populations in Navarra. The presence of new populations of $P$. leniusculus can only be explained as a consequence of crayfish introductions by humans. Similar findings have also been reported in Sweden (BOHMAN et al., 2006). These authors calculated the natural spread of signal crayfish, contrasted it with actual dispersion of this species, and found that human play a major role in the dispersal of this $A$. astaci-carrier. Therefore, the spread of $A$. astaci-carriers by human actions needs to be emphasized when discussing the means of dispersal of the crayfish plague. Many studies on spread on crayfish plague have been focused on other possible means favoring dispersion of spores such as by fish, dead or frozen crayfish, birds, etc (OIDTMANN et al., 2002a, b). However, the possibility of A. astaci being transmitted by other means than introduced crayfish is minimal. A certain quantity of spores is needed to transmit the disease and hence a few spores on a fish or an infected crayfish carried by a bird are not likely to be efficient spreaders of plague (CERENIUS and SÖDERHÄLL, 1999). In crayfish, however, the plague can be spread with efficiency. The spores are protected within the hyphae in the cuticle and can be liberated from there to the new environment.

The dramatic decline of indigenous crayfish in Navarra has started soon after changing management regulations on catching areas for signal crayfish within the "indigenous crayfish area" in 1999. This has made signal crayfish accessible for illegal introductions and this is probably the reason why new populations of signal crayfish are being detected. Some local governments in Spain have not restricted the catching of exotic crayfish considering that this will represent a control measure of unwanted exotic crayfish. Previous studies carried out in the region of Burgos have shown, on the contrary, that allowing open-catching areas for exotic species only favor the dispersal of these crayfish plague-carriers (ALONSO et al., 2000). Similar situations have been reported in Sweden, where it was observed that an increase in number of crayfish plague outbreaks followed as legislation become more liberal to signal crayfish introduction and catching (BOHMAN et al., 2006). This study confirms this observation and points out that uncontrolled catching and poor management of catching areas could facilitate availability of crayfish for illegal introductions. Therefore, urgent changes in regulations for controlling and limiting the captures of exotic crayfish are required to conserve and restore indigenous crayfish populations.

\section{CONCLUSIONS}

1. The main reason for decline of indigenous crayfish populations in Navarra is crayfish plague followed by habitat alterations and climatic drought.

2. Signal crayfish is currently the main factor favoring the dispersal of crayfish plague in Navarra. The swamp crayfish P. clarkii does not appear to be currently involved in the decline of the indigenous crayfish since this species is not being introduced and inhabits watercourses far away from indigenous crayfish.

3. Humans play a major role in the dispersal of carriers of the crayfish plague. Uncontrolled catching and poor management of catching areas facilitate availability of crayfish for illegal introductions. Urgent changes in regulations for controlling and limiting the captures of exotic crayfish are required to preserve and restore indigenous crayfish populations. 


\section{ACKNOWLEDGEMENTS}

This work has been supported by Servicio de Conservación de la Biodiversidad del Gobierno de Navarra, and by project Flora Micológica Ibérica, Ministerio de Educación y Ciencia, Spain. Dr. Frederic Grandjean and Dr. Lage Cerenius are acknowledged for revising the French and English texts, respectively.

\section{REFERENCES}

ALONSO F., TEMIÑO C., DIÉGUEZ-URIBEONDO J., 2000. Status of the white clawed crayfish, Austropotamobius pallipes (Lereboullet, 1858) in Spain: distribution and legislation. Bull. Fr. Pêche Piscic., 356, 31-54.

BOHMAN P., EDSMAN L., NORMAN F., 2006. The effect of large-scale introductions of signal crayfish on the spread of crayfish plague in Sweden 1969-2005. Bull. Fr. Pêche Piscic., 380-381, 1291-1302.

CERENIUS L., SÖDERHÄLL K., 1999. The crayfish plague fungus: history and recent advances. Freshwater Crayfish, 12, 11-35.

CERENIUS L., BANGYEEKHUN E., KEYSER P., SÖDERHÄLL K., 2003. Host prophenoloxidase expression in freshwater crayfish is linked to increased resistance to the crayfish plague fungus, Aphanomyces astaci. Cellular Microbiology, 5, 353-357.

CERENIUS L., SÖDERHÄLL K., PERSSON M., AJAXON R., 1988. The crayfish plague fungus, Aphanomyces astaci - diagnosis, isolation, and pathobiology. Freshwater Crayfish, 7, 131-144.

CUELLAR L., COLL M., 1983. Epizootiology of the crayfish plague (Aphanomycosis) in Spain. Freshwater Crayfish, 5, 545-547.

DIÉGUEZ-URIBEONDO J., SÖDERHÄLL K., 1999. RAPD evidences for the origin of an outbreak of aphanomycosis in Spain. Freshwater Crayfish, 12, 313-318.

DIÉGUEZ-URIBEONDO J., CERENIUS L., SÖDERHÄLL K., 1994. Repeated zoospore emergence in Saprolegnia parasitica. Mycological Research, 98, 810-815.

DIÉGUEZ-URIBEONDO J., HUANG T., CERENIUS L., SÖDERHÄLL K., 1995. Physiological adaptation of an Aphanomyces astaci strain isolated from the freshwater crayfish Procambarus clarkii. Mycological Research, 99, 574-578.

DIÉGUEZ-URIBEONDO J., MÚZQUIZ J.L., 1999. Plan de recuperación del cangrejo autóctono, Austropotamobius pallipes, en Navarra. Trofeo Pesca, 52, 76-78.

DIÉGUEZ-URIBEONDO J., RUEDA A., CASTIÉN E., BASCONES J.C., 1997a. A Plan of restoration in Navarra for the native freshwater crayfish species of Spain, Austropotamobius pallipes. Bull. Fr. Pêche Piscic., 347, 625-637.

DIÉGUEZ-URIBEONDO J., TEMIÑO C., MÚZQUIZ J.C., 1997b. The crayfish plague fungus, Aphanomyces astaci in Spain. Bull. Fr. Pêche Piscic, 347, 753-763.

HUANG T.S., CERENIUS L., SÖDERHÄLL K., 1994. Analysis of genetic diversity in the crayfish plague fungus, Aphanomyces astaci, by random amplification of polymorphic DNA. Aquaculture, 126, 1-10.

LILLEY J.H., CERENIUS L., SÖDERHÄLL K., 1997. RAPD evidence for the origin of crayfish plague outbreaks in Britain. Aquaculture, 157, 181-185.

OIDTMANN B., CERENIUS L., SCHMID I., HOFFMANN R., SÖDERHÄLL K., 1999. Crayfish plague epizootics in Germany-Classification of two German isolates of the crayfish 
plague fungus Aphanomyces astaci by random amplification of polymorphic DNA. Diseases of Aquatic Organisms, 35, 235-238.

OIDTMANN B., HEITZ E., HOFFMANN R.W., ROGERS D., 2002a. On the role of fish and birds in transmitting the crayfish plague fungus, Aphanomyces astaci. Freshwater Crayfish, 13, 613.

OIDTMANN B., HEITZ E., ROGERS D., HOFFMANN R.W., 2002b. Transmission of crayfish plague. Diseases of Aquatic Organisms: 52, 159-167.

ORDEN FORAL 146, 1999. Normativa específica que regirá la pesca en Navarra durante 1999. Boletin Oficial de Navarra, 21.

PERSSON M., SÖDERHÄLL K., 1983. Pacifastacus leniusculus Dana and its resistance to the parasitic fungus Aphanomyces astaci Schikora. Freshwater Crayfish, 5, 292298.

SÖDERHÄLL K., CERENIUS L., 1987. Controlled growth and development in filamentous Oomycetes. with emphasis on Aphanomyces spp. In: Zoosporic Fungi in Teaching and Research, pp. 264-267. M. S. Fuller and A. Jaworski. Southeastern Publishing Corporation, Athens, GA.

SÖDERHÄLL K., DICK D.W., CLARCK G., FÜRST M., CONTANSTINESCU O., 1991. Isolation of Saprolegnia parasitica from the crayfish Astacus leptodactylus. Aquaculture, 92, 121-125.

UNESTAM T., 1969. On the adaptation of Aphanomyces astaci as a parasite. Physiologia Plantarum, 22, 221-235.

UNESTAM T., 1972. On the host range and origin of the crayfish plague fungus. Rep. Inst. Freshw. Res. Drottningholm, 52, 192-198.

VENNERSTRÖM P., SÖDERHÄLL K., CERENIUS L., 1998. The origin of two crayfish plague (Aphanomyces astaci) epizootics in Finland on noble crayfish, Astacus astacus Annales Zoologici Fennici, 35, 43-46.

VEY A., SÖDERHÄLL K., AJAXON R., 1983. Susceptibility of Orconectes limosus to the crayfish plague fungus, Aphanomyces astaci, Freshwater Crayfish, 5, 284-291. 